\title{
頭蓋内狭窄病変
}

一病態と治療—

高木 康志

徳島大学脳神経外科

\section{Intracranial Atherosclerotic Disease : Pathophysiology and Treatment}

\author{
Yasushi Takagi, M.D., Ph.D. \\ Department of Neurosurgery, Tokushima University
}

The recurrence rate of stroke due to intracranial atherosclerotic disease (ICAD) is known to be high. Surgical treatment against ICAD including intravascular surgery doesn't have enough evidence to prevent from recurrence of stroke. In Asian population, ICAD is more common than in European and American population. In this manuscript, recent knowledge about the pathophysiology and the treatment for ICAD are summarized. Especially, different diagnosis and MRI findings of arteriosclerotic ICAD and other ones are shown. In addition, surgical treatment for ICAD in our institute is described.

(Received September 30, 2020; accepted November 4, 2020)

Key words : intracranial atherosclerotic disease, pathophysiology, treatment, MRI

Jpn J Neurosurg（Tokyo） $30: 785^{-792, ~} 2021$

\section{はじめに}

頭蓋内動脈狭窄は，内科的治療によっては再発率が高 いとされ，また現時点で脳血管内治療の有効性について もいまだエビデンスがない，また，欧米に比べアジアで 多いとされている. 本稿では, 頭蓋内狭窄病変について, その病態と治療について述べる。鑑別診断とMRI所見と の関連，現在のエビデンス，さらにはわれわれの施設で の実情を加えて報告する.

\section{頭蓋内狭窄病変の病態}

頭蓋内動脈狭窄においても，頭蓋外血管と同様に Russell Ross の提唱したセオリーに基づいて進行するとされ る。すなわち(1) endothelial dysfunction, (2) fatty streak formation, (3) formation of advanced, complicated lesions, そして(4) unstable fibrous plaques の順に進行する ${ }^{23)}$. ま た，頭蓋内動脈狭窄による脳梗塞はその成因としては， (1) hemodynamic ischemia, (2) in situ thrombosis, (3) artery-to-artery embolism, (4) perforator vessel occlusion, (5) complicated mechanismの5つが挙げられる ${ }^{3226)}$. Incidence としてはアジア人に多いとされている ${ }^{24)}$. 中国 からの報告では全脳梗塞の $20 \sim 46 \%$ を占めるとさ れ27)28)，米国からの報告によれば 8～10\%を占めるとさ れている ${ }^{24)}$ 、リスクファクターとしては，喫煙，高脂血 症，糖尿病，高血圧や肥満との関連が報告されてい

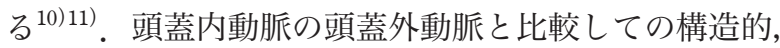
機能的な特徴としては, 筋性動脈としては, 少ない中膜 の弾性線維，薄い中膜，外弾性板の不在，vasa vasorum は内頝動脈や椎骨動脈などの大血管のみに存在，脳冾髄

連絡先：高木康志， $\overline{7} 770-8503$ 徳島市蔵本町 3-18-15 徳島大学脳神経外科

Address reprint requests to : Yasushi Takagi, M.D., Ph.D., Department of Neurosurgery, Tokushima University, 3-18-15 Kuramoto-cho, Tokushima-shi, Tokushima 770-8503, Japan 
液に囲まれた動脈, tight junction の存在, endothelial permeability の減少, 酸化ストレスに対する防御メカニ ズムの発達などが挙げられる ${ }^{22)}$. 頭蓋内動脈の動脈硬化 は欧米人では頭蓋外血管と比較して軽度であることが報 告されている.アジア人, アフリカ人やヒスパニックで は頭蓋外や冠動脈に動脈硬化がない場合に孤立した頭蓋 内病変をしばしばもっていることが指摘されている。 た, 動脈硬化巣が認められる部位は欧米人では内頝動 脈, 頭蓋内椎骨動脈が最も多く, 続いて脳底動脈, 中大 脳動脈, 後大脳動脈, そして前大脳動脈とされる。一方, アジア人では中大脳動脈に最もしばしば変化が認めら れ, 続いて内頚動脈, 脳底動脈, 椎骨動脈, 後大脳動脈, 前大脳動脈と報告されている。また, 多くの報告で小脳 動脈や前交通動脈, 後交通動脈はめつたに変化がないこ と, 内頝動脈で変化が認められるのは主に海綿静脈洞部 と上前床突起部で, 脳底動脈では遠位 $1 / 3$ と近位 $1 / 3$ で

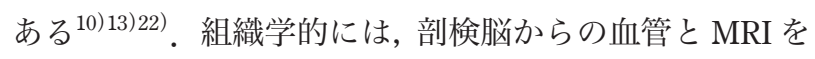
使った報告が行われている。石灰化病変, 脂質に富む部 位, プラーク内出血などの組織内変化と $\mathrm{T} 1$ 強調画像,

$\mathrm{T} 2$ 強調画像, T2 *強調画像などによる MRI での所見が 報告され, 近年の血管壁研究の基礎となってい る13)16)24)28).

\section{鑑別診断と MRI}

頭蓋内動脈狭窄をきたす疾患のうち, 動脈硬化病変以 外の鑑別診断としては, 血管炎, 動脈解離, もやもや病 が挙げられる。もやもや病については近年, RNF213 遺 伝子の関与が報告されているが，頭蓋内狭窄への関与も 報告されている。われわれも家族性もやもや病の家系に おいて, もやもや病のみならず, 片側もやもや病や頭蓋 内動脈狭窄が高頻度に認められること, 類もやもや病に おいてもRNF213 遺伝子の変異が多く認められることを 報告している ${ }^{1820)}$. 鑑別診断としては, 最近頭部 MRIに よる vessel wall imaging (VWI) の重要性が多く報告され ている.VWI は血管腔内の血液信号と血管外の脳凊䯣液 の信号を抑制する撮像法が特徵である.VWIは脳血管撮 影や通常の MRI では評価できない血管壁を評価可能で ある.VWI は Siemens 社では SPACE sequence, Phillips 社では VISTA sequence, GE 社では CUBE sequence が主 に用いられる ${ }^{13)}$. 動脈硬化病変においては局所に偏在性 のプラークが認められる。造影効果もさまざまである。 症候性病変は造影を受けやすい傾向があり, 外側へのリ モデリング, 不整形, プラーク内出血はプラークの不安 定性を示す指標である ${ }^{13) 29)}$ ．血管炎は多発性，分節状，
円滑，全周性の造影病変と血管壁の肥厚が認められる. 造影は狭窄部位のみならず, 狭窄のない部分にも認めら れる.内腔が認められない小血管にも外膜部分に造影が 認められるうえに, 脳表や軟膜にも造影が認められ る ${ }^{13) 29)}$. 動脈解離では VWIにより, intimal flap, double lumen, intramural hematomaを伴う “pearl and string sign” が認められる ${ }^{13) 29)}$. 造影効果はさまざまである. Timeof-flight MRA と比較してVWIにより頭蓋内動脈解離の 診断が $11 \%$ から $22 \%$ に昇したという報告がある.動 脈解離は再発が少なく $(6.2 \%$ vs. $18.6 \%)$, 狭窄の改善が 高率に認められる。

\section{症例提示}

48 歳男性, 右片麻痺にて発症, NIHSS 13 点, 頭部 MRI で左前頭葉に脳梗塞を認めた。脳血管撮影で左前大脳動 脈に不整を認めた（Fig. 1A）。頭部 MRI T1 CUBE gadolinium $(\mathrm{Gd})$ 造影画像にて解離腔，血管壁と血栓を示す と思われる血管壁の造影所見を認めたため, 前大脳動脈 解離による脳梗塞と診断した（Fig. 1B〜D).

\section{頭蓋内動脈狭窄治療のエビデンス}

最近の頭蓋内動脈狭窄病変の治療について, 重要な論 文を 3 つ挙げることができる.1つは WASID trial ${ }^{5)}, 2 つ$ 目は SAMMPRIS trial' ${ }^{6 / 7)}$, もう1つはWEAVE trial ${ }^{1)} の$ 報 告である. WASID trial は 50 99\%の頭蓋内動脈狭窄に 対するワーファリンとアスピリンの効果の比較試験であ る. 死亡, 重篤な出血, 突然死および心筋梗塞はいずれ もアスピリン群で有意に少なかった。また, 虚血性脳卒 中の primary endpoint は両群で差はなかった ${ }^{5)}$.この研究 で明らかになったのは, 頭蓋内狭窄は再発リスクが高 く, 予後が悪い疾患であるということである。この結果 を踏まえ, 頭蓋内動脈狭窄に対する外科的治療への期待 が強く示された結果であった. SAMMPRIS trial は脳内主 幹動脈の 70 99\% 㹨窄による transient ischemic attack (TIA)/脳卒中発症から 30 日以内の後遺障害のない患者 に対する Wingspan stent ${ }^{\circledR}$ (Stryker, USA）を用いたステ ント留置術と積極的内科的治療との比較試験である. 結 果は, 30 日後の脳卒中発症または死亡率を検討したとこ 万, 血管内治療を加えるょり内科治療のみのほうが有意 に低く $(14.7 \%$ vs. $5.8 \%, \mathrm{p}=0.002), 3$ 年後でも, 内科 治療のみのほうでイベント発症が少ない状況は変わらな かった。この結果は積極的内科治療群：アスピリン 325 $\mathrm{mg} /$ 日（追跡期間中）+クロピドグレル $75 \mathrm{mg} /$ 日（90日 

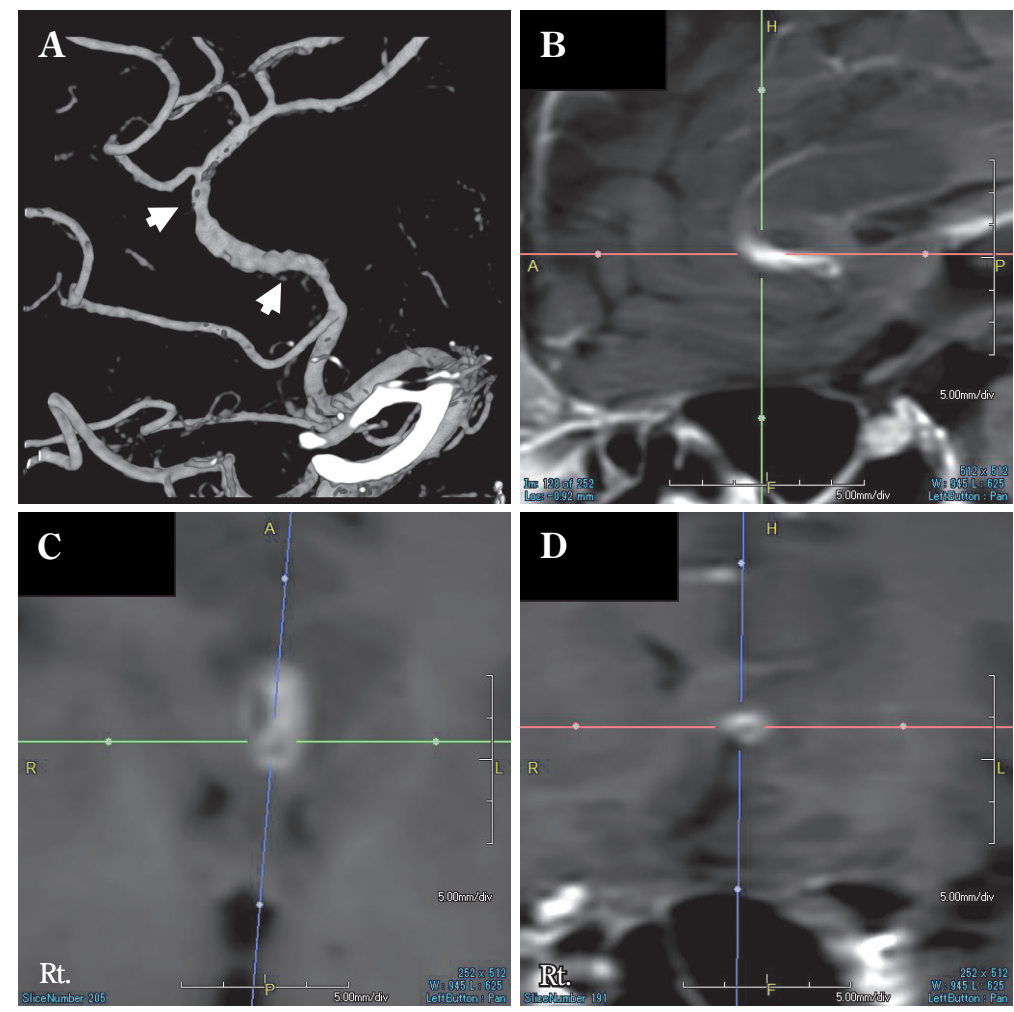

Fig. 1 Illustrated case

A : Three-dimensional reconstructive left internal carotid angiography shows irregular shaped vascular walls (arrows).

B-D : Contrast ${ }^{-}$enhanced magnetic resonance images. B, C, and D represent the sagittal, axial, and coronal sections, respectively of T1 CUBE.

T1 CUBE images show the dissected vascular walls, thrombus, and false lumen of the anterior cerebral artery by the enhanced lesions.

間 $)+$ 降圧治療〔目標 SBP $<140 \mathrm{mmHg}$ (糖尿病は $<130$ $\mathrm{mmHg}$ ) ) 一脂質低下治療 (目標 $\mathrm{LDL}-\mathrm{C}<70 \mathrm{mg} / \mathrm{d} l$ ) +生活 習慣介入 (糖尿病, non-HDL-C, 喫煙, 体重, 運動の評 価とカウンセリング）における脳卒中再発予防効果の高 さを示すとともに, 脳梗塞発症後早期におけるステント 留置術の周術期合併症の多さを示すものであった ${ }^{5) 6}$. WEAVE trial は頭蓋内ステント Wingspan の市販後調査で ある. 使用適応 (22〜 80歳, 症候性頭蓋内狭窄 70 99\%, modified Rankin Scale (mRS) 3 以下, 2 回以上の脳梗塞, 発症から 8 日以上)を満たす 152 人で 72 時間以内の合併 症を調査している。周術期重篤合併症は $2.6 \%$ であり, 発 症後早期を避ければステント留置術の周術期合併症はそ れほど多くないことが示された1).

\section{頭蓋内動脈狭窄治療の現状}

頭蓋内動脈狭窄病変は非常に再発が多いことが示され
ている．前述した WASID trialでは 1 年間の脳卒中再発

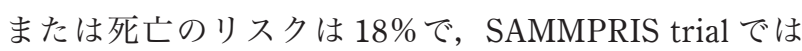
$12.2 \%$ ，内頝動脈閉塞の研究である COSS trial では $16 \%$ である3)5) 7)21) (Table 1)。これらのことを考えても頭蓋 内動脈狭窄病変は予後が悪く，その予後を改善する治療 の確立が望まれていることがわかる。一方，外科的治療 についてであるが，まずは EC-IC bypassについては日本 からの JET study の有効性の報告があるが，海外のデー 夕においては 1987 年の国際共同研究に加え, 2011 年に 報告された COSS trial においても，その効果は否定され ている. COSS trialにおいては完全閉塞内頝動脈の TIA か虚血性脳梗塞 120 日以内の症例において, PET oxygen extraction fraction（OEF）が上昇している195 例 を外科群 97 例, 内科群 98 例に振り分けた. Primary endpoint は術後 30 日以内のすべての stroke and death お よび 2 年以内の同側脳梗塞であった。結果としては 2 年 間での primary endpoint は内科群 $22.7 \%$, 外科群 $21.0 \%$ 
Table 1 1-year stroke and death rates with medical therapy

\begin{tabular}{l|l|c|c}
\hline \multicolumn{1}{c|}{ Medical therapy } & \multicolumn{1}{|c|}{ Publication } & Patients (n) & $\begin{array}{c}\text { One-year } \\
\text { stroke and death } \\
\text { rate }(\%)\end{array}$ \\
\hline WASID $^{5)}$ & New England Journal of Medicine, 2005 & 569 & 18 \\
SAMMPRIS $^{6,7)}$ & New England Journal of Medicine, 2011 & 227 & 12.2 \\
COSS $^{21)}$ & The Journal of the American Medical & 98 & 15.4 \\
Total/mean event rate & Assosiation, 2011 & 894 & 15.4 \\
\hline
\end{tabular}

Table 2 Major Wingspan stent trials with mean time to treatment and complication rates

\begin{tabular}{|c|c|c|c|c|c|}
\hline & Publication & $\begin{array}{l}\text { Patients } \\
\text { stented (n) }\end{array}$ & $\begin{array}{l}\text { Percentage stented } \\
\text { on label for stroke }\end{array}$ & $\begin{array}{c}\text { Periprocedural } \\
\text { complications \%) }\end{array}$ & $\begin{array}{l}\text { Time to stent from } \\
\text { stroke or TIA (days) }\end{array}$ \\
\hline HDE triall) & Stroke, 2007 & 44 & 93 & 4.5 & 22 \\
\hline US registry ${ }^{8 / 9)}$ & $\begin{array}{l}\text { Stroke, } 2007 \\
\text { Stroke, } 2011\end{array}$ & 158 & 57 & 6.9 & Not reported \\
\hline NIH registry ${ }^{33)}$ & Neurology, 2008 & 160 & 61 & 6.2 & 10 \\
\hline SAMMPRIS $^{6 / 7)}$ & $\begin{array}{l}\text { New England Journal } \\
\text { of Medicine, } 2011\end{array}$ & 208 & 8.2 & 14.7 & 7 \\
\hline Jiang ${ }^{12)}$ & Stroke, 2011 & 100 & 71 & 5 & 34 \\
\hline $\operatorname{Miao}^{19)}$ & Stroke, 2015 & 141 & 56 & 4.3 & 19 for TIA $/ 32$ for stroke \\
\hline Zhao ${ }^{31)}$ & $\begin{array}{l}\text { Journal of Stroke and } \\
\text { Cerebrovascular } \\
\text { Diseases, } 2016\end{array}$ & 278 & Not reported & 4.3 & 21 \\
\hline $\mathrm{Gao}^{11)}$ & $\begin{array}{l}\text { American Journal of } \\
\text { Neuroradiology, } \\
2016\end{array}$ & 100 & 50 & 2 & 21 \\
\hline $\mathrm{Ma}^{16)}$ & $\begin{array}{l}\text { Stroke and Vascular } \\
\text { Neurology, } 2018\end{array}$ & 141 & 56 & 4 & 22 \\
\hline WEAVE $^{1)}$ & Stroke, 2019 & 152 & 100 & 2.6 & 22 \\
\hline
\end{tabular}

HDE : humanitarian device exemption, NIH : National Institutes of Health, SAMMPRIS : stenting vs aggressive medical therapy for intracranial artery stenosis, TIA : transient ischaemic attack, WEAVE $:$ Wingspan stent system post market surveillance

と有意差を認めず，加えて 30 日以内の同側脳梗塞が内 科群 $2.0 \%$, 外科群 $14.4 \%$ と外科群の周術期合併症の多 さのため 2 年間の追跡の時点で研究は中止となり, $\mathrm{EC}-$ IC bypass術の優位性は証明されなかった ${ }^{21)}$. ステント留 置術に関しては, SAMMPRIS trialの他に, VISSIT trial よる baloon expandable stent の報告もある。この研究で も 1 年間の stroke または hard TIA はステント治療群で内 科的治療群と比較して有意に多く認められた ${ }^{32}\lceil 36.2 \%$ vs $9.4 \%(\mathrm{p}=0.02)$ ]. 頭蓋内動脈狭窄病変に対するステ ント留置に関しては, 最終発作からの手術までに期間に より，その周術期合併症リスクが異なることが報告され ている(1)46) 9) 11) 12) 16) 19)31)33) (Table 2). 最終発作後中央值 7 日で治療が行われている SAMMPRIS では周術期合併 症は $14.7 \%$ であっのに対し ${ }^{5) 6)}$ ，10日以上の研究では $2.0 \sim 6.2 \%$ であった ${ }^{3)}$ (Table 2). 最終発作後 21 日以上で
ステント留置を行った研究では, 術後 1 年間の脳卒中また は死亡リスクは 5.8 9.5\%であり，これまでに報告され ている内科的治療群の成績と比べ遜色なかった ${ }^{3121215) 16228) 31) ~}$ (Table 3)。これらの結果を踏まえ，現在ステント留置術 は $22 \sim 80$ 歳で, 内科的治療にもかかわらず 2 回以上の発 作があり，最終発作から 7 日より先で治療が見込まれる mRS が 3 以下の患者に対し認められている ${ }^{10)}$ 。また, WEAVE trial 登録症例の 1 年後の評価が WOVEN trial と して今年報告されているが，術後 1 年間の脳卒中または 死亡リスクは 8.5\%であった ${ }^{2)}$ (Table 3)。これらを総合す ると，ステント留置術は症候性頭蓋内動脈狭窄症例に対 して積極的内科的治療が無効であった一部の症例に有効 であると思われる，血管形成術がステント留置と比較し て有効がどうかに関しては, 今後の研究が必要であろう. 
Table 3 1-year stroke and death rates with stenting 21 days or longer after qualifying event

\begin{tabular}{|c|c|c|c|}
\hline Stenting & Publication & Patients (n) & $\begin{array}{c}\text { One-year } \\
\text { stroke and } \\
\text { death rate }(\%)\end{array}$ \\
\hline Jiang $^{12)}$ & Stroke, 2011 & 100 & 7.3 \\
\hline $\mathrm{Li}^{15)}$ & PLoS One, 2015 & 429 & 9.5 \\
\hline Wang $^{28)}$ & Neuroradiology, 2016 & 196 & 9.6 \\
\hline Zhao ${ }^{31)}$ & $\begin{array}{l}\text { Journal of Stroke and Cerebrovascular } \\
\text { Diseases, } 2016\end{array}$ & 278 & 5.8 \\
\hline $\mathrm{Ma}^{16)}$ & Stroke and Vascular Neurology, 2018 & 141 & 7.9 \\
\hline Alexander ${ }^{2)}$ & $\begin{array}{l}\text { Journal of Neurointervention Surgery, } \\
2020\end{array}$ & 129 & 8.5 \\
\hline Total/mean event rate & & 1,273 & 8.1 \\
\hline
\end{tabular}

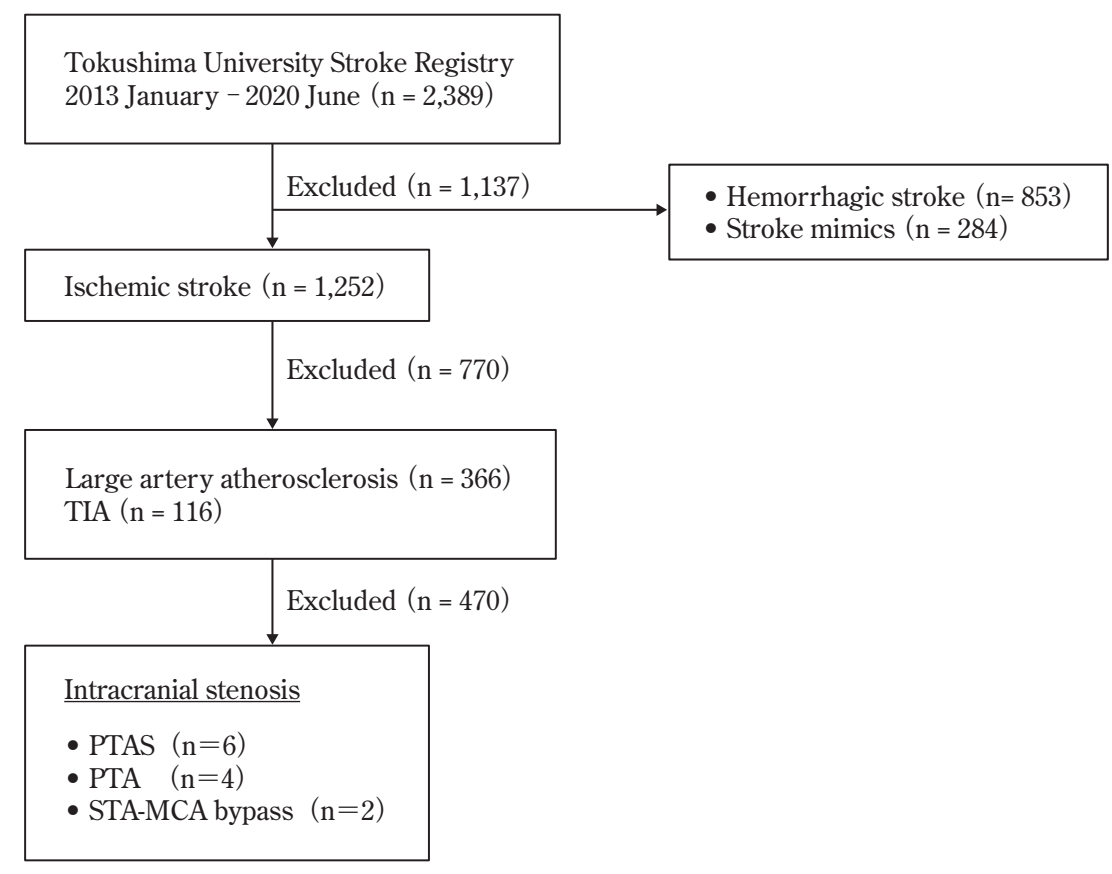

Fig. 2 Intracranial arterial stenosis in Tokushima University Hospital

\section{徳島大学病院脳卒中センターでの経験}

徳島大学病院脳卒中センターでは 2013 年 1 月 2020 年 6 月まで 2,389 例の脳卒中疑いの患者が入院した。そ のうち, 出血性脳卒中 853 例と脳卒中でなかった 284 例 を除き，虚血性脳卒中は 1,252 例であった。そのうち， 頭蓋内動脈狭窄に対しステント留置術を行ったのは 6 例，血管形成術を行ったのは 4 例， STA-MCA bypass を 行ったのは 2 例であった。 ステント留置術を行った症例 は 4 例が脳底動脈に対してで 1 例が内頝動脈，1例が中 大脳動脈であり, 発症後 5 127 日であった。使ったステ ントは Wingspan 4 例, Integrity 2 例であった（Fig. 2,
Table 4).

\section{症例提示}

62 歳男性，複視，顔面神経麻痺，外転神経麻痺にて発 症，NIHSS 3 点，頭部 MRA で脳底動脈の高度狭窄，橋 梗塞を認めた。入院後，内的治療にもかかわらず意識障 害が進行し症状の悪化が認められたため脳血管撮影を施 行した。椎骨動脈造影にて脳底動脈に高度狭窄を認めス テント留置術を行った。術後, 症状の悪化なく経過した (Fig. 3). 
Table 4 Summary of treatment of intracranial arterial stenosis in Tokushima University Hospital

\begin{tabular}{c|c|c|c|c|c|c|l|c|c}
\hline No. & Age, y & Sex & $\begin{array}{c}\text { Lesion } \\
\text { location }\end{array}$ & $\begin{array}{c}\text { Percent } \\
\text { stenosis, } \\
\%\end{array}$ & $\begin{array}{c}\text { Time to } \\
\text { stent, } \\
\text { days }\end{array}$ & Anesthesia & Stent (Diameter-Length) & $\begin{array}{c}\text { Poststent } \\
\text { ballooning }\end{array}$ & $\begin{array}{c}\text { Stroke or } \\
\text { death within } \\
30 \text { days }\end{array}$ \\
\hline 1 & 62 & M & BA & 85 & 5 & Focal & Integrity $(4 \mathrm{~mm}-18 \mathrm{~mm})$ & & - \\
2 & 78 & M & BA & 67 & 11 & Focal & Wingspan $(4 \mathrm{~mm}-20 \mathrm{~mm})$ & & - \\
3 & 56 & M & BA & 60 & 127 & General & Wingspan $(3 \mathrm{~mm}-15 \mathrm{~mm})$ & & - \\
4 & 77 & M & ICA & 99 & 8 & General & Wingspan $(4.5 \mathrm{~mm}-20 \mathrm{~mm})$ & + & - \\
5 & 69 & M & MCA & 60 & 6 & Focal & Wingspan $(2.5 \mathrm{~mm}-9 \mathrm{~mm})$ & + & + \\
6 & 67 & F & BA & 81 & 10 & Focal & Integrity $(2.75 \mathrm{~mm}-12 \mathrm{~mm})$ & & - \\
\hline
\end{tabular}

$\mathrm{BA}$ : basilar artery, ICA : internal carotid artery, MCA : middle cerebral artery
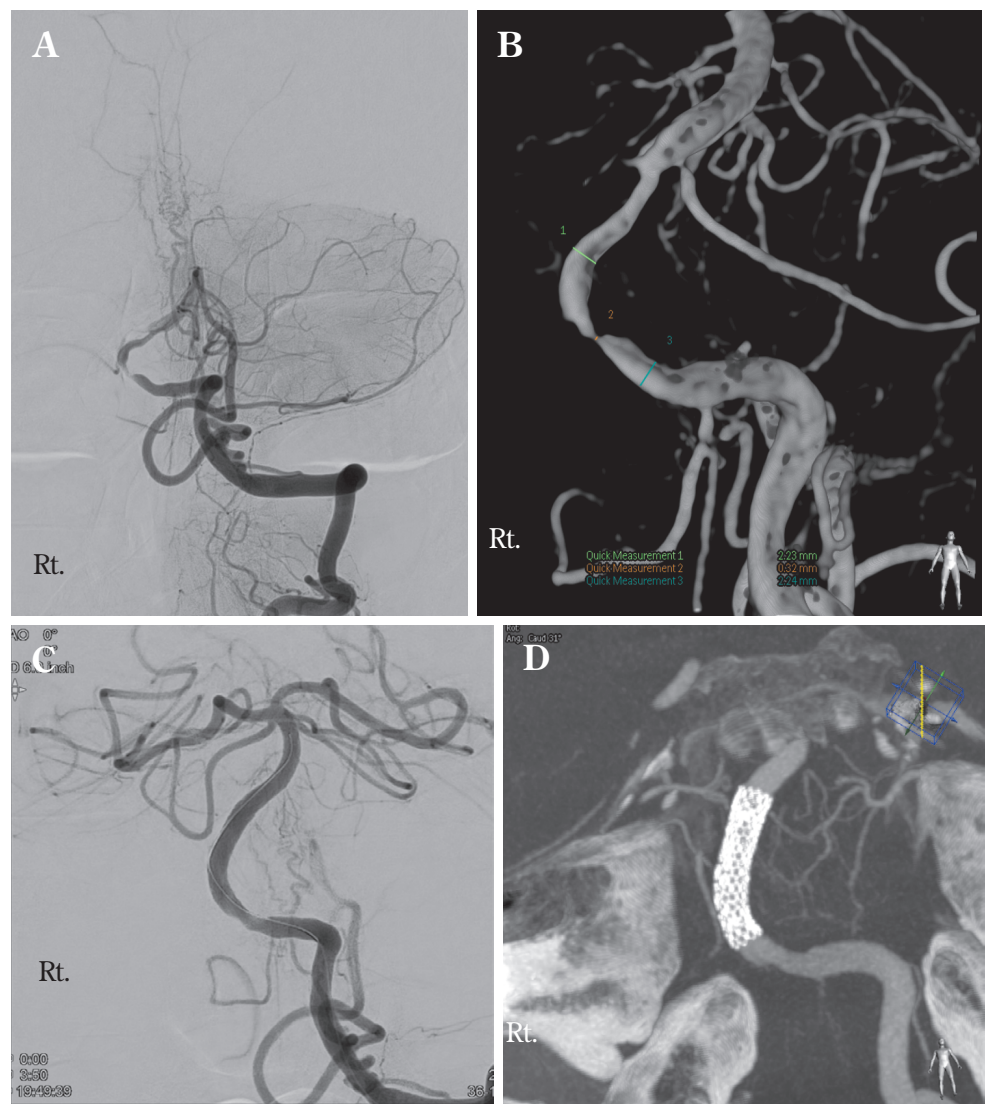

Fig. 3 Illustrated case

A : Left vertebral angiography reveals severe basilar artery stenosis.

B : Three-dimensional (3-D) reconstructive angiographic image shows severe basilar artery stenosis.

C : Left vertebral angiography after stent placement shows improvement in the basilar artery stenosis.

D : 3-D reconstructive angiographic image of the basilar artery shows the stent placement.

\section{まとめ}

頭蓋内動脈狭窄病変は虚血性脳卒中の主な原因の 1 つ であり，再発リスクも比較的高い疾患である。内科的治
療としては，抗血小板療法に加え積極的なリスク因子の 制御と生活習慣の改善が挙げられる。最近の MRIによる VWI の進歩による，頭蓋内血管狭窄の組織学的診断が鑑 別診断には有用である。またステント留置術も含めた治 
療法の最適化には，現時点でも至っておらず，今後の臨 床研究が必要であると思われる。

\section{COI}

著者は日本脳神経外科学会への COI 自己申告の登録を完了 しており，筆頭著者が過去 3 年 1〜12 月において本論文に関 して開示すべき COI は下記のとおりです。第一三共製薬より 講演料（年間合計 100 万円以上）

\section{文 献}

1) Alexander MJ, Zauner A, Chaloupka JC, Baxter B, Callison RC, Gupta R, Song SS, Yu W ; WEAVE Trial Sites and Interventionalists : WEAVE Trial : final results in 152 On-Label patients. Stroke 50:889-894, 2019.

2) Alexander MJ, Zauner A, Gupta R, Alshekhlee A, Fraser JF, Toth G, Given C, Mackenzie L, Kott B, Hassan AE, Shownkeen H, Baxter BW, Callison RC, Yu W: The WOVEN trial: Wingspan one-year vascular events and neurologic outcomes. J Neurointerv Surg $13: 307-310,2021$.

3) Barnard ZR, Alexander MJ : Update in the treatment of intracranial atherosclerotic disease. Stroke Vasc Neurol 5: 59-64, 2019.

4) Bose A, Hartmann M, Henkes H, Liu HM, Teng MM, Szikora I, Berlis A, Reul J, Yu SC, Forsting M, Lui M, Lim W, Sit SP : A novel, self-expanding, nitinol stent in medically refractory intracranial atherosclerotic stenoses : the Wingspan study. Stroke $38:$ 1531-1537, 2007.

5) Chimowitz MI, Lynn MJ, Howlett-Smith H, Stern BJ, Hertzberg VS, Frankel MR, Levine SR, Chaturvedi S, Kasner SE, Benesch CG, Sila CA, Jovin TG, Romano JG ; WarfarinAspirin Symptomatic Intracranial Disease Trial Investigators: Comparison of warfarin and aspirin for symptomatic intracranial arterial stenosis. N Engl J Med 352 : 13051316, 2005.

6) Chimowitz MI, Lynn MJ, Derdeyn CP, Turan TN, Fiorella D, Lane BF, Janis LS, Lutsep HL, Barnwell SL, Waters MF, Hoh BL, Hourihane JM, Levy EI, Alexandrov AV, Harrigan MR, Chiu D, Klucznik RP, Clark JM, McDougall CG, Johnson MD, Pride GL Jr, Torbey MT, Zaidat OO, Rumboldt Z, Cloft HJ ; SAMMPRIS Trial Investigators : Stenting versus aggressive medical therapy for intracranial arterial stenosis. NEngl J Med $365:$ 993-1003, 2011.

7) Derdeyn CP, Chimowitz MI, Lynn MJ, Fiorella D, Turan TN, Janis LS, Montgomery J, Nizam A, Lane BF, Lutsep HL, Barnwell SL, Waters MF, Hoh BL, Hourihane JM, Levy EI, Alexandrov AV, Harrigan MR, Chiu D, Klucznik RP, Clark JM, McDougall CG, Johnson MD, Pride GL Jr, Lynch JR, Zaidat OO, Rumboldt Z, Cloft HJ ; Stenting and Aggressive Medical Management for Preventing Recurrent Stroke in Intracranial Stenosis Trial Investigators : Aggressive medical treatment with or without stenting in high-risk patients with intracranial artery stenosis (SAMMPRIS) : the final results of a randomised trial. Lancet $383: 333-341,2014$.

8) Fiorella D, Levy EI, Turk AS, Albuquerque FC, Niemann DB, Aagaard-Kienitz B, Hanel RA, Woo H, Rasmussen PA, Hopkins LN, Masaryk TJ, McDougall CG : US multicenter experience with the wingspan stent system for the treatment of intracranial atheromatous disease : periprocedural results. Stroke 38:881-887, 2007.

9) Fiorella DJ, Turk AS, Levy EI, Pride GL Jr, Woo HH, Albu- querque FC, Welch BG, Niemann DB, Aagaard-Kienitz B, Rasmussen PA, Hopkins LN, Masaryk TJ, McDougall CG : U. S. Wingspan Registry: 12-month follow-up results. Stroke 42:1976-1981, 2011.

10) Flusty B, de Havenon A, Prabhakaran S, Liebeskind DS, Yaghi S : Intracranial atherosclerosis treatment : past, present, and future. Stroke 51: e49-e53, 2020.

11) Gao P, Wang D, Zhao Z, Cai Y, Li T, Shi H, Wu W, He W, Yin L, Huang S, Zhu F, Jiao L, Ji X, Qureshi AI, Ling F : Multicenter prospective trial of stent placement in patients with symptomatic high-grade intracranial stenosis. AJNR Am J Neuroradiol 37: 1275-1280, 2016.

12) Jiang WJ, Yu W, Du B, Gao F, Cui LY : Outcome of patients with $\geq 70 \%$ symptomatic intracranial stenosis after Wingspan stenting. Stroke $\quad 42: 1971-1975,2011$.

13) Kern KC, Liebeskind DS : Vessel wall imaging of cerebrovascular disorders. Curr Treat Options Cardiovasc Med $21: 65,2019$.

14) Kwee RM, Qiao Y, Liu L, Zeiler SR, Wasserman BA : Temporal course and implications of intracranial atherosclerotic plaque enhancement on high-resolution vessel wall MRI. Neuroradiology 61: 651-657, 2019.

15) Li TX, Gao BL, Cai DY, Wang ZL, Zhu LF, Xue JY, Bai WX, He YK, Li L : Wingspan stenting for severe symptomatic intracranial atherosclerotic stenosis in 433 patients treated at a single medical center. PLoS One $\quad 10: \mathrm{e} 0139377,2015$.

16) Ma N, Zhang Y, Shuai J, Jiang C, Zhu Q, Chen K, Liu L, Li B, Shi X, Gao L, Liu Y, Wang F, Li Y, Liu T, Zheng H, Mo D, Gao F, Wang Y, Wang Y, Feng L, Miao Z : Stenting for symptomatic intracranial arterial stenosis in China : 1-year outcome of a multicentre registry study. Stroke Vasc Neurol 3: 176-184, 2018.

17) Mandell DM, Matouk CC, Farb RI, Krings T, Agid R, terBrugge K, Willinsky RA, Swartz RH, Silver FL, Mikulis DJ : Vessel wall MRI to differentiate between reversible cerebral vasoconstriction syndrome and central nervous system vasculitis : preliminary results. Stroke $43: 860^{-}$ 862, 2012.

18) Matsuda Y, Mineharu Y, Kimura M, Takagi Y, Kobayashi H, Hitomi T, Harada KH, Uchihashi Y, Funaki T, Miyamoto S, Koizumi A : RNF213 p.R4810K variant and intracranial arterial stenosis or occlusion in relatives of patients with moyamoya disease. J Stroke Cerebrovasc Dis 26 : 1841-1847, 2017.

19) Miao Z, Zhang Y, Shuai J, Jiang C, Zhu Q, Chen K, Liu L, Li B, Shi X, Gao L, Liu Y, Wang F, Li Y, Liu T, Zheng H, Wang Y, Wang Y ; Study Group of Registry Study of Stenting for Symptomatic Intracranial Artery Stenosis in China : Thirtyday outcome of a multicenter registry study of stenting for symptomatic intracranial artery stenosis in China. Stroke 46: 2822-2829, 2015.

20) Morimoto T, Mineharu Y, Kobayashi H, Harada KH, Funaki T, Takagi Y, Sakai N, Miyamoto S, Koizumi A : Significant association of the RNF213 p.R4810K polymorphism with quasi-moyamoya disease. J Stroke Cerebrovasc Dis 25 : 2632-2636, 2016.

21) Powers WJ, Clarke WR, Grubb RL Jr, Videen TO, Adams HP Jr, Derdeyn CP ; COSS Investigators : Extracranial-intracranial bypass surgery for stroke prevention in hemodynamic cerebral ischemia : the Carotid Occlusion Surgery Study randomized trial. JAMA 306: 1983-1992, 2011.

22) Ritz K, Denswil NP, Stam OC, van Lieshout JJ, Daemen MJ : 
Cause and mechanisms of intracranial atherosclerosis. Circulation 130: 1407-1414, 2014.

23) Ross R: The pathogenesis of atherosclerosis - An update. $N$ Engl JMed 314: 488, 1986.

24) Sacco RL, Kargman DE, Gu Q, Zamanillo MC : Race-ethnicity and determinants of intracranial atherosclerotic cerebral infarction. The Northern Manhattan stroke study. Stroke 26: 14-20, 1995.

25) Shin J, Chung JW, Park MS, Lee H, Cha J, Seo WK, Kim GM, Bang OY : Outcomes after ischemic stroke caused by intracranial atherosclerosis vs dissection. Neurology $\mathbf{9 1}$ : e1751-e1759, 2018.

26）植田敏浩：症候性頭蓋内動脈狭窄の内科的治療と脳血管 内治療の現状. 脳外誌 26:714-720, 2017.

27) Wang Y, Zhao X, Liu L, Soo YO, Pu Y, Pan Y, Wang Y, Zou X, Leung TW, Cai Y, Bai Q, Wu Y, Wang C, Pan X, Luo B, Wong KS ; CICAS Study Group: Prevalence and outcomes of symptomatic intracranial large artery stenoses and occlusions in China: the Chinese Intracranial Atherosclerosis (CICAS) Study. Stroke 45:663-669, 2014.

28) Wang ZL, Gao BL, Li TX, Cai DY, Zhu LF, Xue JY, Bai WX, Li ZS : Outcomes of middle cerebral artery angioplasty and stenting with Wingspan at a high-volume center. Neuroradiology 58: 161-169, 2016.

29) van der Kolk AG, Zwanenburg JJ, Denswil NP, Vink A, Spliet WG, Daemen MJ, Visser F, Klomp DW, Luijten PR, Hen- drikse $\mathrm{J}$ : Imaging the intracranial atherosclerotic vessel wall using 7 T MRI : initial comparison with histopathology. AJNR Am J Neuroradiol $36: 694-701,2015$.

30) Wong KS, Huang YN, Gao S, Lam WW, Chan YL, Kay R : Intracranial stenosis in Chinese patients with acute stroke. Neurology 50: 812-813, 1998.

31) Zhao T, Zhu WY, Xiong XY, Li J, Wang L, Ding HY, Wei F, Zhou Y, Gong ZL, Cheng SY, Liu Y, Shuai J, Yang QW : Safety and efficacy of Wingspan stenting for severe symptomatic atherosclerotic stenosis of the middle cerebral artery: analysis of 278 continuous cases. J Stroke Cerebrovasc Dis 25: 2368-2372, 2016.

32) Zaidat OO, Fitzsimmons BF, Woodward BK, Wang Z, KillerOberpfalzer M, Wakhloo A, Gupta R, Kirshner H, Megerian JT, Lesko J, Pitzer P, Ramos J, Castonguay AC, Barnwell S, Smith WS, Gress DR ; VISSIT Trial Investigators : Effect of a balloon-expandable intracranial stent vs medical therapy on risk of stroke in patients with symptomatic intracranial stenosis: the VISSIT randomized clinical trial. JAMA 313: 1240-1248, 2015.

33) Zaidat OO, Klucznik R, Alexander MJ, Chaloupka J, Lutsep H, Barnwell S, Mawad M, Lane B, Lynn MJ, Chimowitz M ; NIH Multi-center Wingspan Intracranial Stent Registry Study Group: The NIH registry on use of the Wingspan stent for symptomatic $70-99 \%$ intracranial arterial stenosis. Neurology $\quad \mathbf{7 0}:$ 1518-1524, 2008.

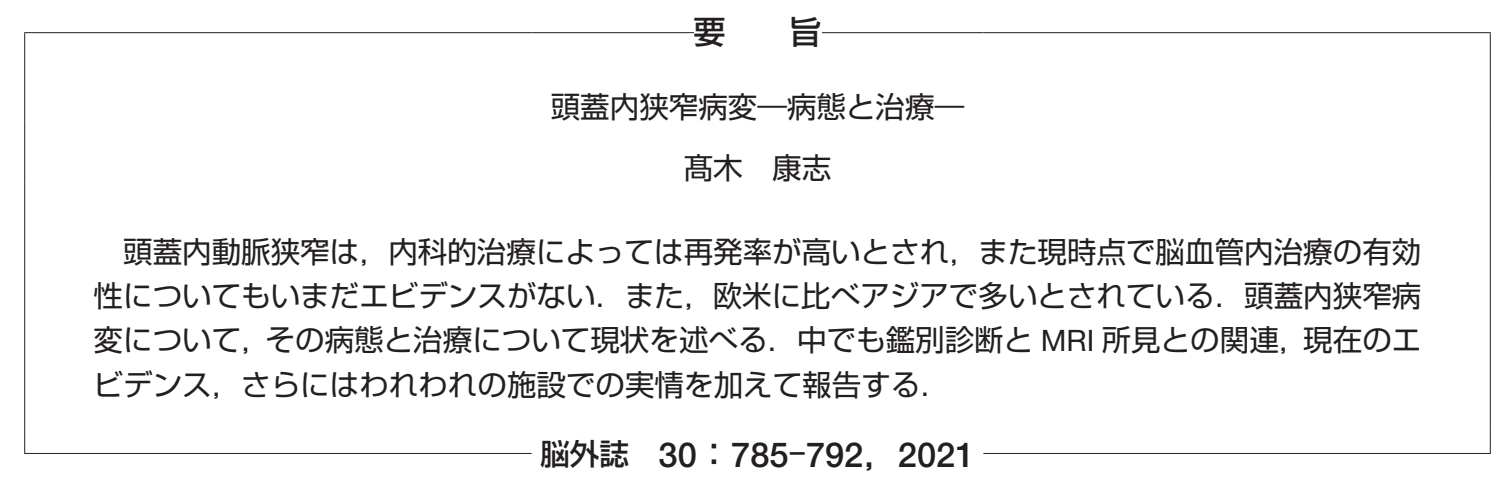

